\title{
Allelopathic Potential of Eucalyptus rostrata Leaf Residue on Some Metabolic Activities of Zea mays $L$.
}

\author{
Hegab, M. M. ${ }^{1, *}$, Gabr, M. A. ${ }^{2}$, Al-Wakeel, S. A. M. ${ }^{1}$,Hamed, B. A. ${ }^{2}$ \\ ${ }^{1}$ Department of Botany and Microbiology, Faculty of Science, Cairo University, Beni-Suef Branch, Egypt \\ ${ }^{2}$ Department of Botany, Faculty of Science, Cairo University, Egypt
}

Copyright $\mathrm{O} 2016$ by authors, all rights reserved. Authors agree that this article remains permanently open access under the terms of the Creative Commons Attribution License 4.0 International License

\begin{abstract}
A greenhouse pot experiment was conducted to investigate the possible allelopathic effect of Eucalyptus rostrata leaf residue on some metabolic activities associated with growth of 10, 20 and 30 - day - old corn plants. The lower level of Eucalyptus treatment $(0.5 \%$, w/w) induced a stimulatory effect on the growth of shoot and root of corn plants. The positive effect was more obvious in shoot than in root growth. Inversely, high levels of incorporated Eucalyptus leaf residue (1 and $2 \%, \mathrm{w} / \mathrm{w}$ ) reduced all growth parameters of both shoot and root relative to the respective control, and this reduction was concentration dependent. The total phenolic aglycone content of mature Eucalyptus leaf was $16.89 \mathrm{mg} \mathrm{g}^{-1}$ dry weight present as water-soluble secondary metabolites. Qualitative and quantitative HPLC analysis of Eucalyptus rostrata leaves revealed the presence of nine phenolic compounds. The $p$-coumaric acid was the most dominant compound, while catechol and chlorogenic acid were detected in lesser amounts. A trace amount of salicylic acid, vanillin, coumarin, as well as caffeic, cinnamic and ferulic acids were also detected. The total phenolic content of corn shoot increased with the lower concentration of Eucalyptus residue and decreased with higher treatments. The lowest level of Eucalyptus residue $(0.5 \%, \mathrm{w} / \mathrm{w})$ increased the contents of photosynthetic pigments, particularly chlorophyll " $a$ " content, which was correlated with increase in the total carbohydrate production. Similarly, the total nitrogen and total phosphorus, as well as nucleic acids were markedly higher than the control treatment. Negative pattern of changes in the contents of photosynthetic pigments, carbohydrate, nitrogen, phosphorus, phenolic compounds and nucleic acids, was observed in corn plant treated with high rates of Eucalyptus leaf residue ( 1 and $2 \%, \mathrm{w} / \mathrm{w})$ as compared with their respective controls. These negative effects were concentration dependent.
\end{abstract}

Keywords Phenolic Compounds, Growth, Pigments and Metabolic Activities

\section{Introduction}

Eucalyptus (Family: Myrtaceae) includes about 150 species, seven of these species are cultivated in Egypt, most of them are trees of large size (Boulos and El-Hadidi, 1988). Eucalyptus trees are evergreen, and propagated only from seeds. The poor performance of crops beneath the tree area related to the allelopathic effect of Eucalyptus (Singh and Kohli, 1992; Anaya, 1999). Allelochemicals are naturally released from intact living or dead Eucalyptus tissues and accumulate in soil rhizosphere in concentrations high enough to produce allelopathic effects. Milled or chopped Eucalyptus parts release allelochemicals more rapidly than intact parts (May and Ash, 1990; Espinosa-Garcia, 1996). Leaf extracts, decaying leaves and soil collected under Eucalyptus canopies inhibited seed germination and seedling growth of associated species (Suresh and Vinaya Rai, 1987; Konar and Kushari, 1995). On the other hand, Kumar (1986) reported that a single row of Eucalyptus growing along field boundaries increased the yield of many crop plants. Lisanework and Michelsen (1993) demonstrated that aqueous leaf extracts of Eucalyptus trees significantly reduced both germination and radical growth of chickpea, maize and pea mostly at high concentrations. The inhibitory effects of leaf extract were higher than stem extracts (Phlomina and Srivasuki, 1996; Balasubramanian and Ravichandran, 1996; Sajjan et al., 1997).

A wide range of secondary metabolites have been identified in Eucalyptus species, including phenolic acids, flavonoids, tannins, coumarins, wax and terpenoids (Salama et al., 1990; Huang et al., 1994; Nishimura and Mizutani, 1995; Sivagurunathan et al., 1997).

Corn (Zea mays L.) is one of the most important cereal crops growing in the Arab Republic of Egypt. It is used as a food for human consumption and also as a feed grain for animals. In a field study, Igboanugo (1988) found that beans could be incompatible with Eucalyptus, while maize may be compatible with Eucalyptus for agrosilvicultural practices.

In the present investigation, Eucalyptus rostrata tree is used to study its allelopathic potential on some biochemical changes associated with the growth of corn (Zea mays L.). 


\section{Materials and Methods}

Fresh mature leaves of a 7-year-old Eucalyptus rostrata (Schlecht not Cav.) tree were collected from the campus of Cairo University, Beni-Suef Branch, Egypt. The leaves were air dried, ground to fine powder and sieved through $2 \mathrm{~mm}$-mesh screen. Corn (Zea mays L.) grains were kindly obtained from the Agricultural Research Center, Ministry of Agriculture, Egypt.

The pot experiment was carried out under natural conditions in a plastic pot ( $25 \mathrm{~cm}$ diameter x $15 \mathrm{~cm}$ length), containing $2 \mathrm{~kg}$ of a mixture of clay-sandy $(2: 1, \mathrm{w} / \mathrm{w})$ soil. The soil was incorporated with 10,20 or $40 \mathrm{~g}$ of powdered Eucalyptus leaf tissue at $2 \mathrm{~cm}$ depth that gave $0.5,1$ or $2 \%$ (w/w, residue/soil). The pots were divided into four groups including the control and the three different concentrations of Eucalyptus leaf residue. Each treatment was replicated twelve times in a completely randomized experimental design. Each pot was planted with ten grains of corn at $3 \mathrm{~cm}$ depth. After emergence, the seedlings were thinned to 6 healthy seedlings per pot. Pots were maintained in a greenhouse under natural conditions of light with a 14 hours photoperiod and average $30 / 13^{\circ} \mathrm{C} \pm 3^{\circ} \mathrm{C}$ day/night temperatures. Plants were irrigated daily with tap water to maintain soil moisture near field capacity.

The plant samples were harvested after 10,20 and 30 days from sowing, separated into root and shoot, then washed thoroughly with distilled water. The lengths of shoot and root were measured and their fresh weights were recorded. The samples were dried in an oven at $60^{\circ} \mathrm{C}$ to constant weight. The water content of each organ was calculated on a dry weight basis. The shoot was ground to fine powder and kept in dry condition for the biochemical analyses.

Photosynthetic pigments of the fresh corn shoot tissues were extracted and determined according to the method described by Fadeel (1962). The contents of chlorophylls " $a$ " and " $b$ ", as well as and carotenoids were calculated according to equations adopted by Sestak et al. (1971).

The extraction of nucleic acids was carried out by the method cited by Mohamed and El-Sayed (1982). DNA and RNA content were measured by diphenylamine and orcinol reactions, respectively (Clark and Switzer, 1977) and calculated according to the equations outlined by Schneider (1945).

The dried powder shoot tissues were extracted with $80 \%$ ethanol by refluxing for one hour (Jindal and Singh, 1975) for estimating the phenolic content using Folin-Ciocalteau reagent (AOAC, 1990). The soluble reducing sugars were estimated in the ethanolic extract by Nelson's reaction (Clark and Switzer, 1977). The non-reducing sugars were hydrolyzed in the ethanolic extract with $6 \mathrm{~N} \mathrm{HCl}$ (Gaines, 1973), whereas the insoluble carbohydrates in the remaining dry residue were hydrolyzed with $0.2 \mathrm{~N} \mathrm{H}_{2} \mathrm{SO}_{4}$ in boiling water bath for one hour (Streeter and Jeffers, 1979). The reducing values of the hydrolyzed samples were measured by Nelson's reaction.

Total nitrogen and phosphorus were determined in the acid digested samples using Berthelot reaction (Chaney and Marbach, 1962) and modified Fiske-Subbarow method (Clark and Switzer, 1977), respectively. Soluble nitrogen and phosphorus were extracted from the dried shoot tissue with $10 \%$ TCA and the dried residue was acid digested to obtain the insoluble fractions. The amino- $\mathrm{N}$ was estimated in the TCA extract according to the method described by Russell (1944).

HPLC analysis of the allelochemicals in the Eucalyptus rostrata leaves was analyzed on a Hewlett-Packard HPLC system, fitted with a reverse-phase Ultrasphere $\mathrm{C}_{18}$ hypersil column $(250 \times 4.60 \mathrm{~mm}), 25 \mu \mathrm{m}$ particle size. The mobile phase: acetonitril-acetic acid (30:70, v/v) was used over 48 min. All data were analyzed with two-way ANOVA program (Campbell, 1989).

\section{Results and Discussion}

Chemical analysis of mature Eucalyptus rostrata leaves contained $16.89 \mathrm{mg} \mathrm{g}^{-1}$ dry weight phenolic aglycones as water soluble secondary metabolites. Qualitative analysis of the phenolic content of Eucalyptus leaves by HPLC revealed the presence of several peaks (Figure 1), and only nine phenolic aglycones were identified (Table 1). Among the identified aglycones in Eucalyptus extract, $p$-coumaric acid constituted the major component. The two other aglycones catechol and chlorogenic acid were detected in a lesser amount. Salicylic acid, vanillin and coumarin were also identified, two relatively small fractions of caffeic acid and cinnamic acid, whereas ferulic acid was found in a trace amount.

In this respect, Srivastava et al. (1996) demonstrated that the most principal allelochemicals are phenolic glycosides in Eucalyptus tereticornis. Sivagurunathan et al. (1997) reported that litter of Eucalyptus species released more phenolic compounds than other plant parts and most of these compounds are phenolic acids, including caffeic, coumaric, gallic, gentisic, hydroxybenzoic, syringic and vanillic acids in addition to catechol. Recently, Gallet et al. (1999) showed that Eucalyptus hermaphraditum leaves and aqueous leaf extracts have high levels of phenolics, which are the most stable compounds. 
Table 1. The quantitative and qualitative analysis of phenolic aglycones of Eucalyptus rostrata leaves using HPLC.

\begin{tabular}{|c|c|c|c|}
\hline \multirow{2}{*}{ Phenolic Compound } & \multicolumn{2}{|c|}{ Retention Time (min.) } & \multirow{2}{*}{$\begin{array}{c}\text { Concentration } \\
\mathrm{\mu g}^{-1} \text { dry weight }\end{array}$} \\
\cline { 2 - 3 } & Standard & Sample & -- \\
\hline Pyrogallic acid & 6.17 & -- & -- \\
\hline Resrcinol & 10.89 & -- & -- \\
\hline Protocatechuic acid & 11.46 & -- & $1172 \pm 0.31$ \\
\hline Catechol & 12.64 & 13.76 & -- \\
\hline$p$-hydroxybenzoic acid & 15.98 & -- & $956 \pm 0.08$ \\
\hline Chlorogenic acid & 16.81 & 16.33 & $58 \pm 0.15$ \\
\hline Caffeic acid & 19.50 & 19.43 & -- \\
\hline Syringic acid & 20.28 & -- & $122 \pm 0.09$ \\
\hline Vanillin & 22.88 & 21.96 & $4750 \pm 1.67$ \\
\hline$p$-Coumaric acid & 24.65 & 24.15 & $1.53 \pm 0.01$ \\
\hline Ferulic acid & 25.09 & 25.49 & $115 \pm 0.03$ \\
\hline Coumarin & 29.47 & 29.25 & $148 \pm 0.07$ \\
\hline Salicylic acid & 30.92 & 31.27 & $29 \pm 0.04$ \\
\hline Cinnamic acid & 34.56 & 33.94 & -- \\
\hline Kaempferol & 39.29 & -- & \\
\hline
\end{tabular}

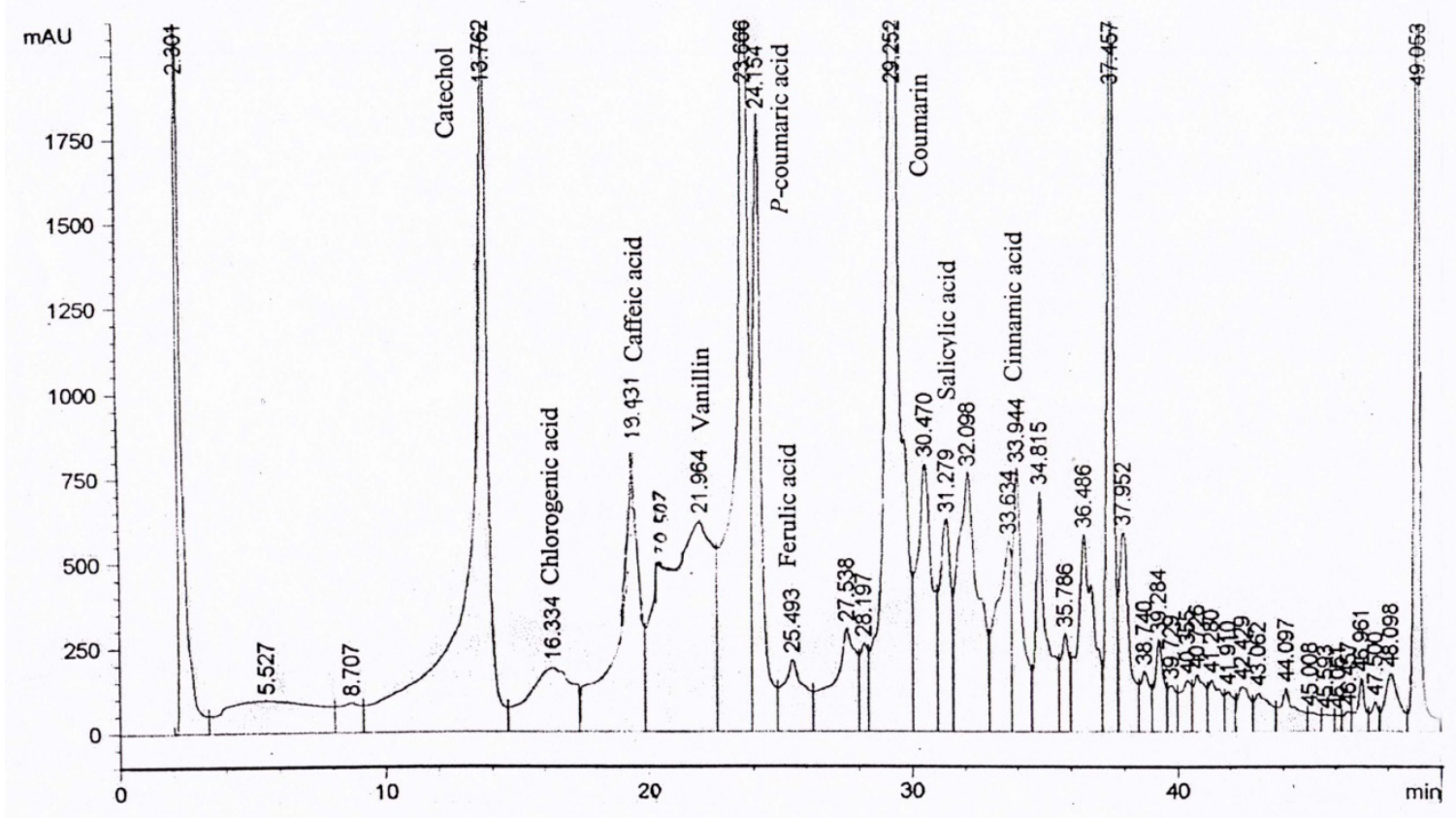

Figure 1. HPLC chromatogram of Eucalyptus rostrata leaf phenolic aglycones. 
Table 2. Alleopathic effect of Eucalyptus rostrata leaf residue on the root growth criteria of Zea mays plant at different growth periods.

\begin{tabular}{|c|c|c|c|c|c|}
\hline \multicolumn{6}{|c|}{ Root Growth } \\
\hline \multirow{2}{*}{$\begin{array}{l}\text { Age/ } \\
\text { (days) }\end{array}$} & \multirow{2}{*}{$\begin{array}{l}\text { Residue Rate } \\
\text { (w/w) }\end{array}$} & \multirow{2}{*}{$\begin{array}{l}\text { Length } \\
(\mathrm{cm})\end{array}$} & \multicolumn{2}{|c|}{ Plant Weight (g) } & \multirow{2}{*}{$\begin{array}{l}\text { Water content } \\
\left(\mathrm{g} \mathrm{H}_{2} \mathrm{O} \mathrm{g}^{-1} \mathrm{DW}\right)\end{array}$} \\
\hline & & & Fresh & Dry & \\
\hline \multirow{4}{*}{10} & Control & $9.2 \pm 0.58$ & $1.82 \pm 0.11$ & $0.19 \pm 0.006$ & $8.58 \pm 0.25$ \\
\hline & $0.5 \%$ & $10.5 \pm 0.50$ & $2.12 \pm 0.11$ & $0.22 \pm 0.013$ & $8.64 \pm 0.89$ \\
\hline & $1.0 \%$ & $7.8 \pm 1.00$ & $1.51 \pm 0.02$ & $0.17 \pm 0.015$ & $7.88 \pm 0.89$ \\
\hline & $2.0 \%$ & $6.0 \pm 0.76$ & $1.15 \pm 0.02$ & $0.14 \pm 0.009$ & $7.21 \pm 0.77$ \\
\hline \multirow{4}{*}{20} & Control & $10.5 \pm 0.50$ & $2.48 \pm 0.37$ & $0.25 \pm 0.040$ & $8.92 \pm 1.30$ \\
\hline & $0.5 \%$ & $12.3 \pm 0.29$ & $2.52 \pm 0.14$ & $0.24 \pm 0.010$ & $9.50 \pm 1.18$ \\
\hline & $1.0 \%$ & $10.1 \pm 0.29$ & $1.92 \pm 0.09$ & $0.21 \pm 0.003$ & $8.14 \pm 0.25$ \\
\hline & $2.0 \%$ & $7.6 \pm 0.58$ & $1.53 \pm 0.04$ & $0.18 \pm 0.010$ & $7.50 \pm 0.47$ \\
\hline \multirow{4}{*}{30} & Control & $16.0 \pm 1.00$ & $6.48 \pm 0.50$ & $0.62 \pm 0.007$ & $9.45 \pm 0.74$ \\
\hline & $0.5 \%$ & $18.6 \pm 0.58$ & $6.93 \pm 0.19$ & $0.63 \pm 0.013$ & $10.00 \pm 0.08$ \\
\hline & $1.0 \%$ & $14.3 \pm 0.58$ & $5.81 \pm 0.06$ & $0.59 \pm 0.048$ & $8.85 \pm 0.64$ \\
\hline & $2.0 \%$ & $11.6 \pm 0.58$ & $4.34 \pm 0.03$ & $0.48 \pm 0.035$ & $8.04 \pm 0.86$ \\
\hline
\end{tabular}

Table 3. Alleopathic effect of Eucalyptus rostrata leaf residue on the shoot growth criteria of Zea mays plant at different growth periods.

\begin{tabular}{|c|c|c|c|c|c|}
\hline \multicolumn{6}{|c|}{ Shoot Growth } \\
\hline \multirow{2}{*}{$\begin{array}{l}\text { Age/ } \\
\text { (days) }\end{array}$} & \multirow{2}{*}{$\begin{array}{l}\text { Residue Rate } \\
(\mathrm{w} / \mathrm{w})\end{array}$} & \multirow{2}{*}{$\begin{array}{l}\text { Length } \\
(\mathrm{cm})\end{array}$} & \multicolumn{2}{|c|}{ Plant Weight (g) } & \multirow{2}{*}{$\begin{array}{l}\text { Water content } \\
\left(\mathrm{g} \mathrm{H}_{2} \mathrm{O} \mathrm{g} \mathrm{g}^{-1} \mathrm{DW}\right)\end{array}$} \\
\hline & & & Fresh & Dry & \\
\hline \multirow{4}{*}{10} & Control & $10.6 \pm 0.76$ & $7.4 \pm 0.37$ & $0.64 \pm 0.020$ & $10.56 \pm 0.72$ \\
\hline & $0.5 \%$ & $12.5 \pm 0.50$ & $8.9 \pm 0.34$ & $0.73 \pm 0.030$ & $11.20 \pm 0.05$ \\
\hline & $1.0 \%$ & $9.3 \pm 0.58$ & $6.2 \pm 0.12$ & $0.55 \pm 0.003$ & $10.27 \pm 0.16$ \\
\hline & $2.0 \%$ & $6.8 \pm 0.76$ & $4.7 \pm 0.58$ & $0.47 \pm 0.020$ & $9.00 \pm 1.49$ \\
\hline \multirow{4}{*}{20} & Control & $12.3 \pm 0.58$ & $12.1 \pm 0.24$ & $1.20 \pm 0.030$ & $9.10 \pm 0.13$ \\
\hline & $0.5 \%$ & $14.8 \pm 0.29$ & $14.0 \pm 0.33$ & $1.29 \pm 0.030$ & $9.85 \pm 0.03$ \\
\hline & $1.0 \%$ & $13.0 \pm 0.00$ & $12.9 \pm 0.69$ & $1.23 \pm 0.060$ & $9.50 \pm 0.57$ \\
\hline & $2.0 \%$ & $9.6 \pm 0.58$ & $8.3 \pm 0.59$ & $0.87 \pm 0.060$ & $8.54 \pm 0.02$ \\
\hline \multirow{4}{*}{30} & Control & $15.01 \pm 0.29$ & $26.4 \pm 0.15$ & $3.09 \pm 0.060$ & $7.54 \pm 0.74$ \\
\hline & $0.5 \%$ & $19.3 \pm 0.58$ & $32.9 \pm 1.48$ & $3.62 \pm 0.140$ & $8.10 \pm 0.08$ \\
\hline & $1.0 \%$ & $16.3 \pm 0.58$ & $30.7 \pm 0.46$ & $3.44 \pm 0.143$ & $7.92 \pm 0.64$ \\
\hline & $2.0 \%$ & $11.3 \pm 0.58$ & $20.2 \pm 0.12$ & $2.62 \pm 0.236$ & $6.71 \pm 0.86$ \\
\hline
\end{tabular}

The incorporation of Eucalyptus residue at lower rate of $(0.5 \%)$ induced a stimulatory effect in all growth parameters of both root and shoot of Zea mays. The magnitude of promotion in all growth parameters was more pronounced in shoot than root as compared with their respective control at each growth stage (Table, $2 \& 3$ ). However, increasing the level of incorporated Eucalyptus leaf residue up to $1 \%$ induced a pronounced reduction in all growth parameters of the root, but slightly stimulated the length, fresh and dry weights as well as water content of shoot of 20- and 30-day-old plants relative to the control (Table 3). The highest level of Eucalyptus leaf residue (2\%) induced a marked reduction in the various growth parameters of both root and shoot, where the reduction was more obvious in root than in shoot.

This finding is in agreement with the results of Jayakumar et al. (1990) who showed that the irrigation of groundnut and maize with $5,10,15$ and $20 \%$ water extract of abscised 
Eucalyptus globulus leaf greatly reduced plant height and leaf area. Recently, Abu El-Soud (2001) demonstrated stimulation in pea growth parameters by increasing the rate of the incorporated Acacia nilotica leaf residue from 0.25 $0.5 \%(\mathrm{w} / \mathrm{w})$, but gradual suppression at 1.5 to $2 \%(\mathrm{w} / \mathrm{w})$. In this respect, Rice (1984) related the reduction in plant growth to the inhibitory effect of allelopathic compounds on IAA biosynthesis and on gibberellic acid induction. Furthermore, Schon and Einhellig (1982) attributed the inhibition of sorghum growth by sunflower leaf residue to the decrease in leaf water potential $\left(\Psi_{\mathrm{w}}\right)$ that affected water utilization, which in turn affect cell turgidity and hence cell enlargement. Recently, Reigosa et al. (1999) assumed that allelopathic compounds are affecting many different physiological processes simultaneously and these effects are concentration dependent.

The phenolic contents of corn plant treated with different levels of Eucalyptus leaf residue showed variable changes (Fig. 2). The lowest level of Eucalyptus leaf residue (0.5\%) induced an accumulation of the total phenolic compounds which was more pronounced in phenolic glycosides than phenolic aglycones throughout experimental periods of 10 , 20 and 30 days. However, increasing Eucalyptus leaf residue level was accompanied by a marked increase in the phenolic aglycone contents, while contents of the phenolic glycoside was greatly reduced at the different stages of growth. The obvious reduction in total phenolics at the higher levels of Eucalyptus allelochemicals, could be due to their depressive effects on the enzyme systems involved in phenol biosynthesis. In this regard, Sato et al. (1982) early demonstrated that the activity of phenylalanine ammonia-lyase decreased markedly upon treatment with cinnamic acid derivatives. This enzyme catalyzes the first step reactions in phenolic pathway (Cosio and Mc Clure, 1984). Usually, the sugar units bind to the free aglycones at the late stage of biosynthesis forming phenolic glycosides, which become non-toxic, more water-soluble and easily translocate to non-photosynthetic tissues (Hrazdina and Wagner, 1985). In this respect, Kleiner et al. (1999) demonstrated that the phenolic glycosides are mainly synthesized within the chloroplast and representing plant defense metabolites. The production of phenolic glycosides may be effective in protecting corn plant treated with lowest Eucalyptus rostrata $(0.5 \%)$ against the external stress conditions. This is true where high accumulation of phenolic glycosides, reduces the phytotoxic effects of Eucalyptus allelochemicals.

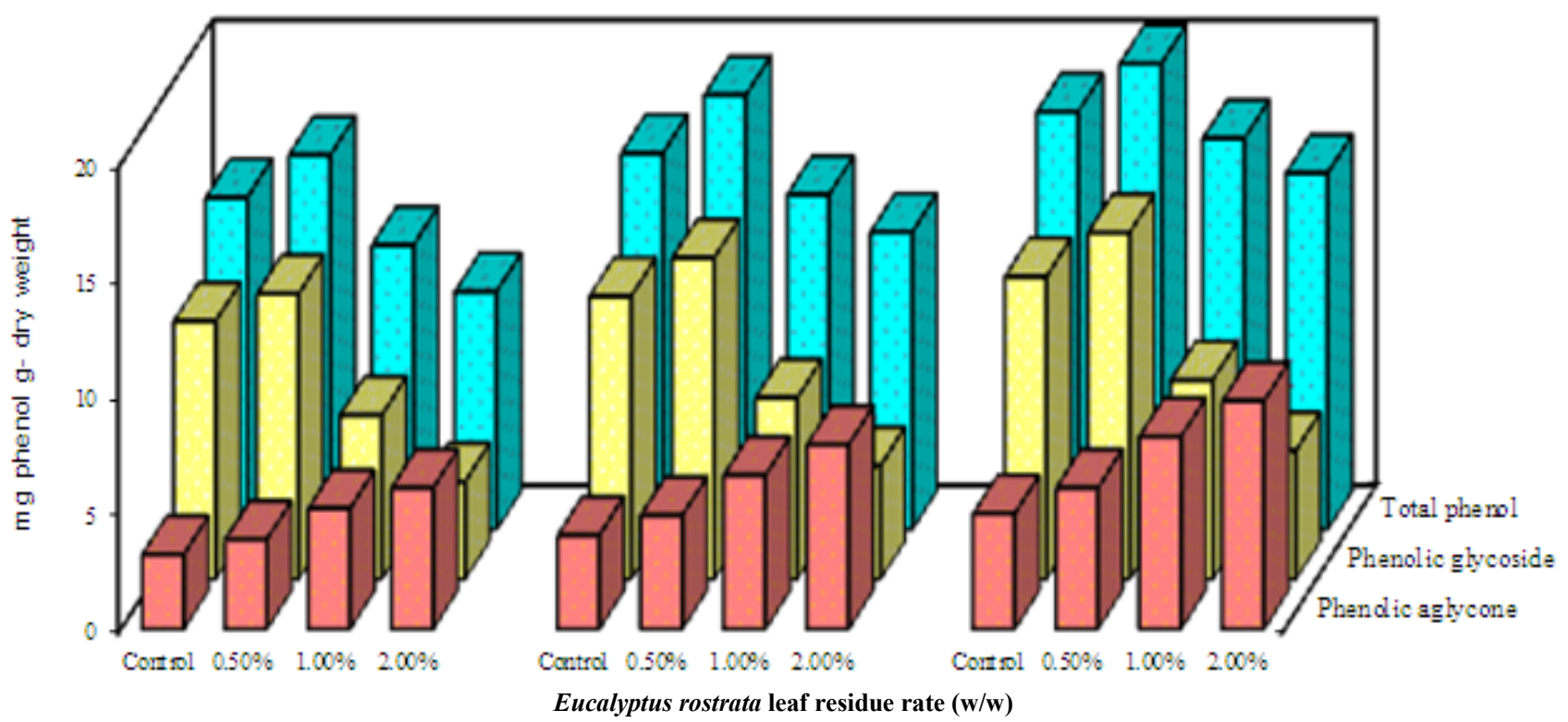

Time $=\mathrm{P}<0.001$ (except in phenolic glycoside $\mathrm{P}<0.05$ ), Treatment $=\mathrm{P}<0.001$ and Time-treatment interaction $=\mathrm{P}>0.05$.

Figure 2. Allelopathic effect of Eucalyptus rostrata leaf residue on the phenolic content of Zea mays plant at different growth periods. 


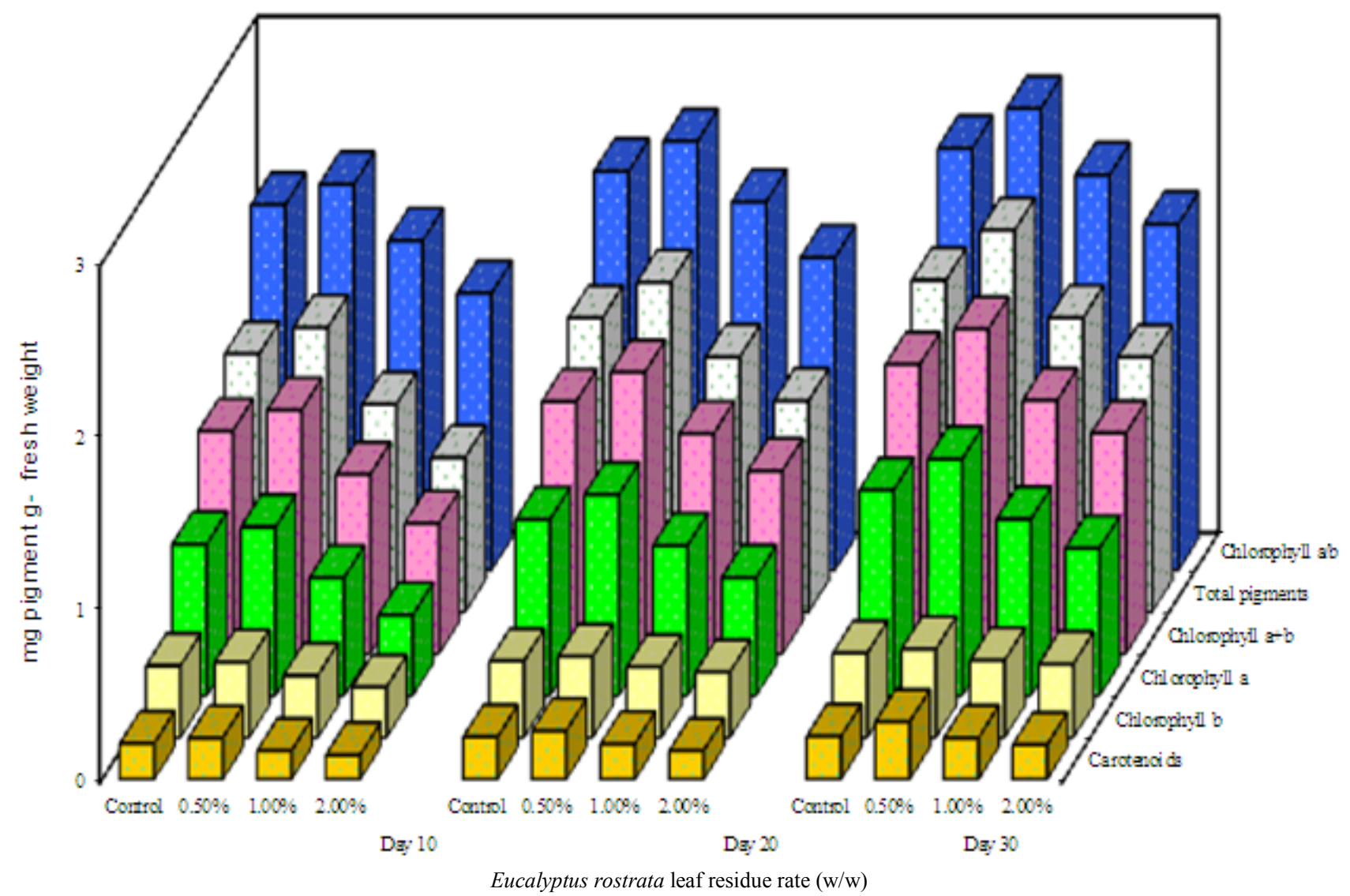

Time $=\mathrm{P}<0.001$, Treatment $=\mathrm{P}<0.001$ and Time-treatment interaction $=\mathrm{P}>0.05$

Figure 3. Allelopathic effect of Eucalyptus rostrata leaf residue on the photosynthetic pigment contents of Zea mays plant at different growth periods.

The incorporation of Eucalyptus leaf residue at lowest level $0.5 \%(\mathrm{w} / \mathrm{w})$ caused a stimulatory effect on the accumulation of chlorophyll " $a$ " and " $b$ ", as well as carotenoids in the shoot of corn plants (Fig. 3). It obvious that such effect was more pronounced in carotenoids content. In contrast, the applications of Eucalyptus leaf residue above $0.5 \%$ induced reduction in contents of different pigment fractions, at each growth stage. This reduction was more obvious in chlorophyll " $a$ " than in other pigments as compared with respective control. This could be possibly related to the degradation mechanisms of chlorophyll " $a$ " and " $b$ ", and / or to the reduction in the capacity to biosynthesis of new chlorophylls. These results agree with those obtained by Kohli et al. (1991) and Konar and Kushari (1995) using Eucalyptus extract on different crop plants. Prasad and Subhashini (1994) showed that the allelochemicals greatly inhibited porphyrin synthesis.

The application of Eucalyptus leaf residue at lower rate $(0.5 \%)$, increased the total carbohydrate content in corn shoot at different plant ages (Fig. 4). This stimulatory effect was attributed to the accumulation in the insoluble sugar fraction and to the decline in the total soluble sugar fraction, as compared with their respective controls. Increasing concentration of Eucalyptus leaf residue above $0.5 \%$ induced a greater reduction in the level of different carbohydrate fractions. However, the highest concentration (2\%) induced the maximum inhibition in the contents of all sugar fractions, particularly the non-reducing sugar. These findings are in harmony with the result of Al-Wakeel and Soliman (1994) show that low concentration of lupin seed extract increased the level of the total carbohydrate content in the shoot of 60-day-old soybean, while the high concentration reduced these parameters. Similarly, Tripathi et al. (1998) showed that the total sugar content in soybean leaves increased as a result of treatment with 5\% concentration of Acacia leaf extract, whereas, the 10 and $20 \%$ extracts reduced this accumulation. Recently, Abu El-Soud (2001) demonstrated that pea plant grown in soil incorporated with 0.25 and $0.5 \%$ $(\mathrm{w} / \mathrm{w})$ Acacia leaf residue for 45 days accumulated a large amount of carbohydrates than those grown in higher concentration of Acacia treatments. Under the present experimental condition, the reduction in chlorophyll " $a$ " content consequently reduces the photosynthetic efficiency of the corn shoot and inturn reduces the accumulation of carbohydrate. This could account for the reduction in dry weight of corn plants treated with high levels of Eucalyptus rostrata. This explanation is consistent with the previous results obtained by other workers for adverse effects of allelochemicals application that could limit carbohydrate synthesis in many plant species (Mersie and Singh, 1993; Einhellig, 2001). Furthermore, it is well established that the phenolic compounds (sorgeolon and juglone) are powerful inhibitors of chloroplast $\mathrm{CO}_{2}$-dependent oxygen evolution (Hejl et al., 1993; Jose and Gillispie, 1998). 


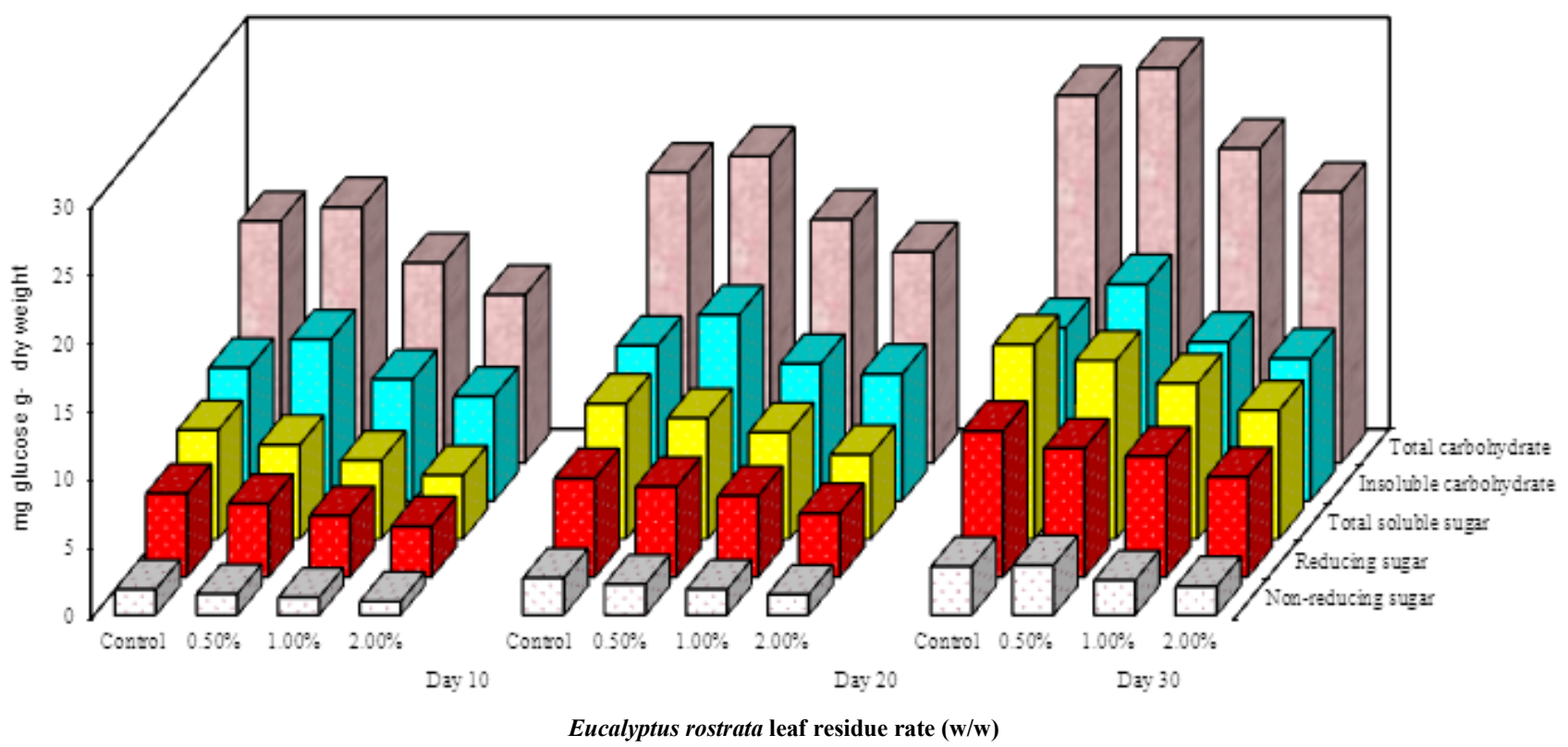

Time $=\mathrm{P}<0.001$, Treatment $=\mathrm{P}<0.001$ and Time-treatment interaction $=\mathrm{P}>0.05$

Figure 4. Allelopathic effect of Eucalyptus rostrata leaf residue on the carbohydrate contents of Zea mays plant at different growth periods.

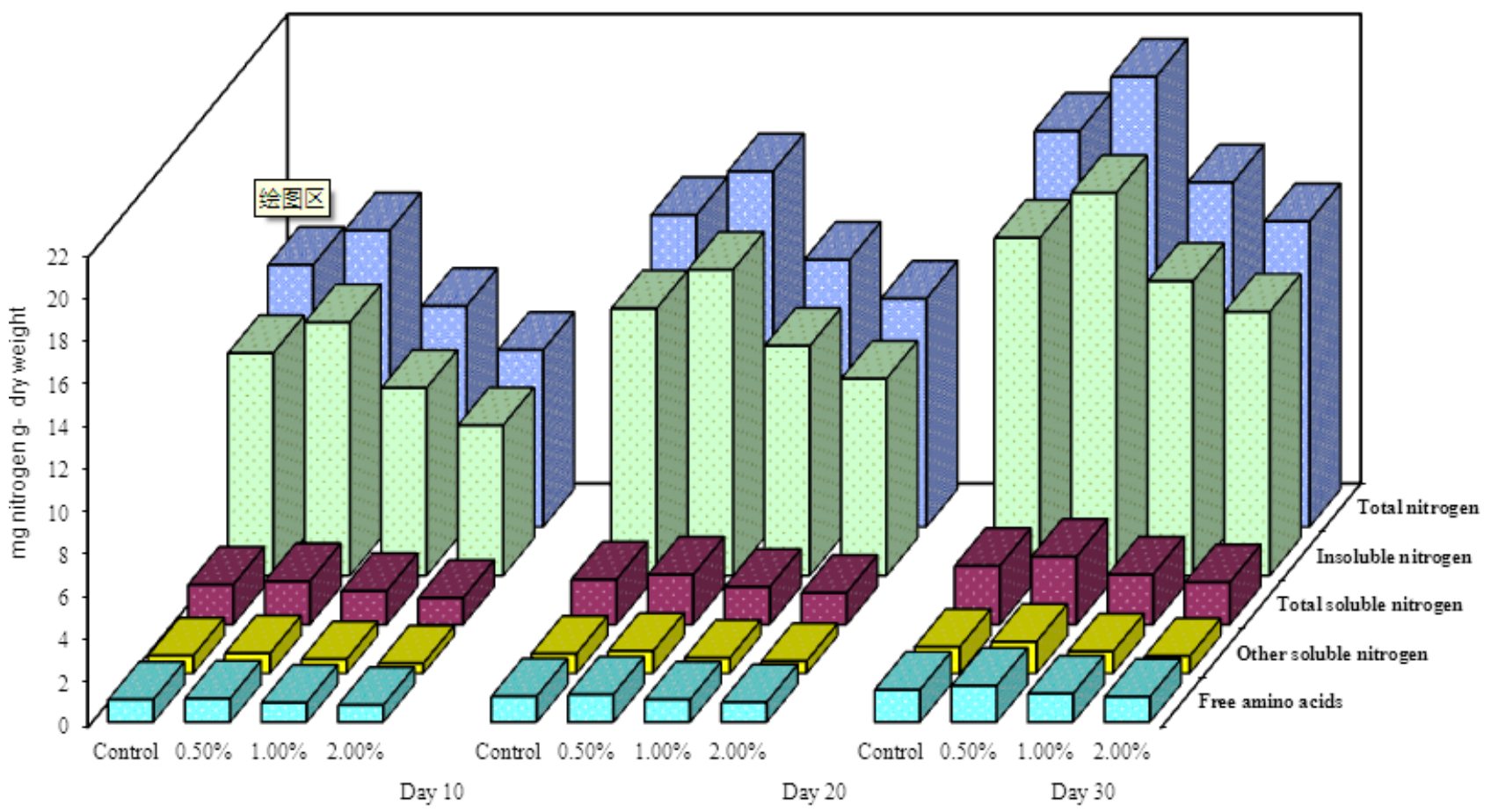

Eucalyptus rostrata leaf residue rate $(\mathrm{w} / \mathrm{w})$

Time $=\mathrm{P}<0.001$, Treatment $=\mathrm{P}<0.001$ and Time-treatment interaction $=\mathrm{P}>0.05$

Figure 5. Allelopathic effect of Eucalyptus rostrata leaf residue on the nitrogen contents of Zea mays plant at different growth periods.

Figure (5) shows that the incorporation of Eucalyptus leaf residue at $0.5 \%(\mathrm{w} / \mathrm{w})$ level induced an obvious increase in the soluble, insoluble and total nitrogen contents. This indicates that the lowest Eucalyptus treatment may have a stimulatory effect on the nitrogen uptake and have the potential to enhance the enzyme system involved in the incorporation of amino acids into the insoluble form (e.g. protein synthesis). This result in support the data obtained by Tripathi et al. (1998), who showed an increase in protein content of soybean over the control by application of leaf extract of Albizia procera and Acacia nilotica. On contrast, the incorporation of Eucalyptus leaf residue with high concentrations ( 1 and $2 \%, w / w)$ reduced the contents of both soluble and insoluble nitrogen, and the reduction was concentration dependent. These results are in agreement with that reported in Costus species treated with Eucalyptus globulus leaches (Konar and Kushari, 1995). Also, Balasubramanian and Ravichandran (1996) showed that 
allelochemicals of Eucalyptus tereticornis and other agroforestry trees inhibited the legume-rhizobium symbiosis and interfered with the subsequent nodulation and nitrogen fixation. Furthermore, the application of phenolic acids (caffeic, vanillic, $p$-coumaric, chlorogenic and ferulic acid) greatly reduced the nitrogen content of 3-week old tomato leaf (Mersie \& Singh, 1988). The variable effects of Eucalyptus allelochemicals on corn nitrogen content could be explained on the basis of the interference of the allelopathic substances with nitrogen uptake and metabolism. Moreover, Cameron and Julian (1980) demonstrated the inhibition of protein content upon treatment with cinnamic and ferulic acids by depression of ${ }^{14} \mathrm{C}$-tyrosine incorporation into protein in Lactuca sativa L. seedlings. In accordance with this hypothesis, it was found that benzoic, cinnamic and ferulic acids inhibited the incorporation of ${ }^{35} \mathrm{~S}$-methionine into protein in soybean seedlings, whereas $p$-hydroxybenzoic and $p$-coumaric acids increased its uptake (Baziramakenga et al., 1997).

Application of Eucalyptus leaf residue at $0.5 \%$ caused a marked increase in both soluble and insoluble phosphorus as well as the total phosphorus contents in the corn shoot, as compared with their respective controls at each growth stage (Fig. 6). This result suggests that the low levels of Eucalyptus allelochemicals have stimulatory effect on the uptake and assimilation of phosphorus. These results are in accordance with Baziramakenga et al. (1994), who reported that low concentrations of phenolic acids ( $p$-hydroxybenzoic and $p$-coumaric acids) slightly increase phosphorus absorption by roots of soybean plant. Inversely, the higher levels of Eucalyptus allelochemicals (1 and 2\%) reduced the amount of all phosphorus fractions, possibly due to their interference with phosphorus uptake and assimilation. Similarly, the results agree with those of Mersie and Singh (1988) who demonstrated that Parthenium hysterophorus extract and residue greatly reduced phosphorus content of treated 3-week old tomato plant leaf. Other investigators showed that the allelochemicals, mainly phenolic acids, obviously reduced the phosphorus content in various plants by interference with the phosphate and anion uptake, as well as membrane permeability (Prasad and Rama Devi, 2001).

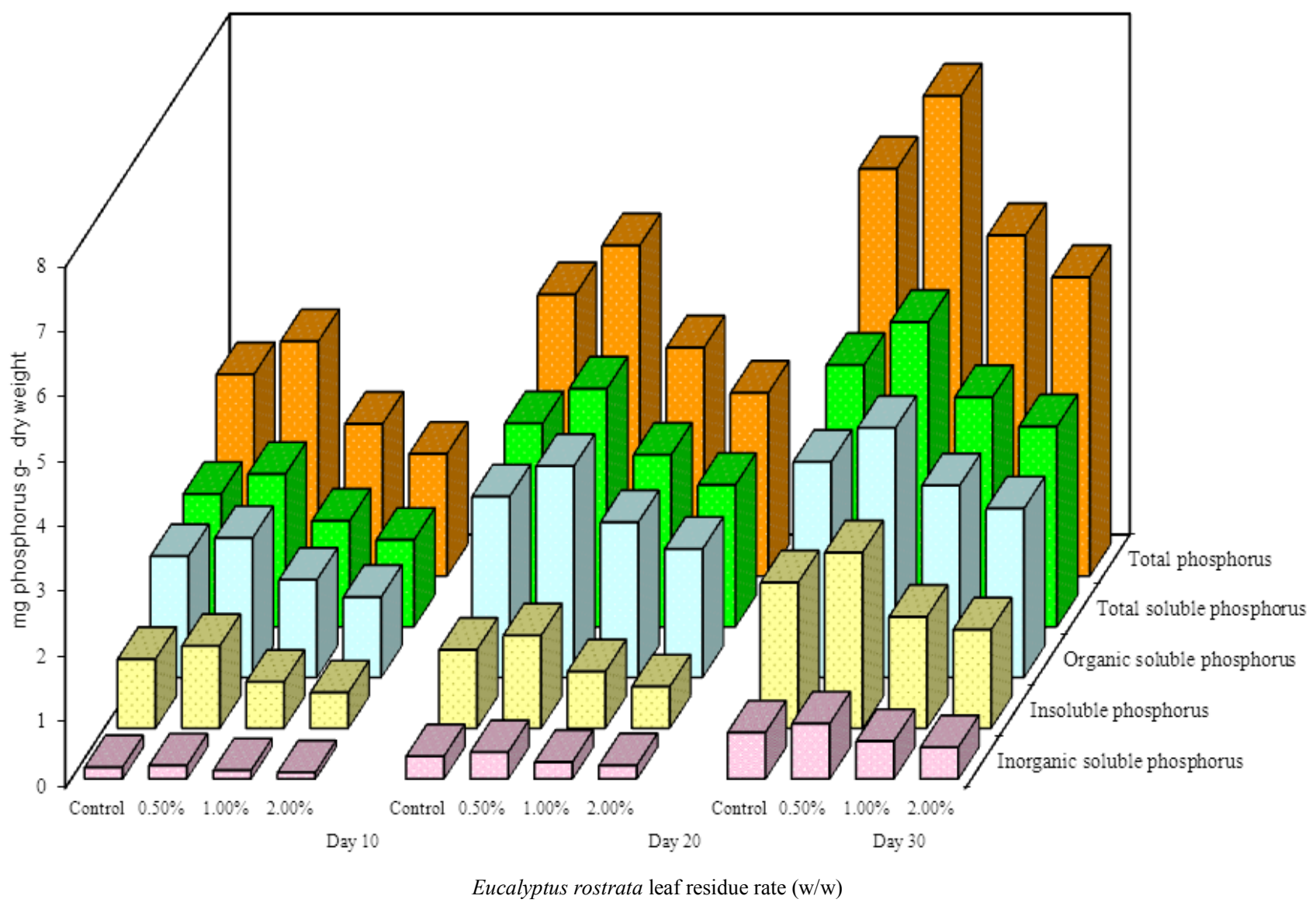

Time $=\mathrm{P}<0.001$, Treatment $=\mathrm{P}<0.001$ and Time-treatment interaction $=\mathrm{P}>0.05$ (except in total phosphorus $\mathrm{p}<0.05$ ).

Figure 6. Allelopathic effect of Eucalyptus rostrata leaf residue on the phosphorus contents of Zea mays plant at different growth periods. 


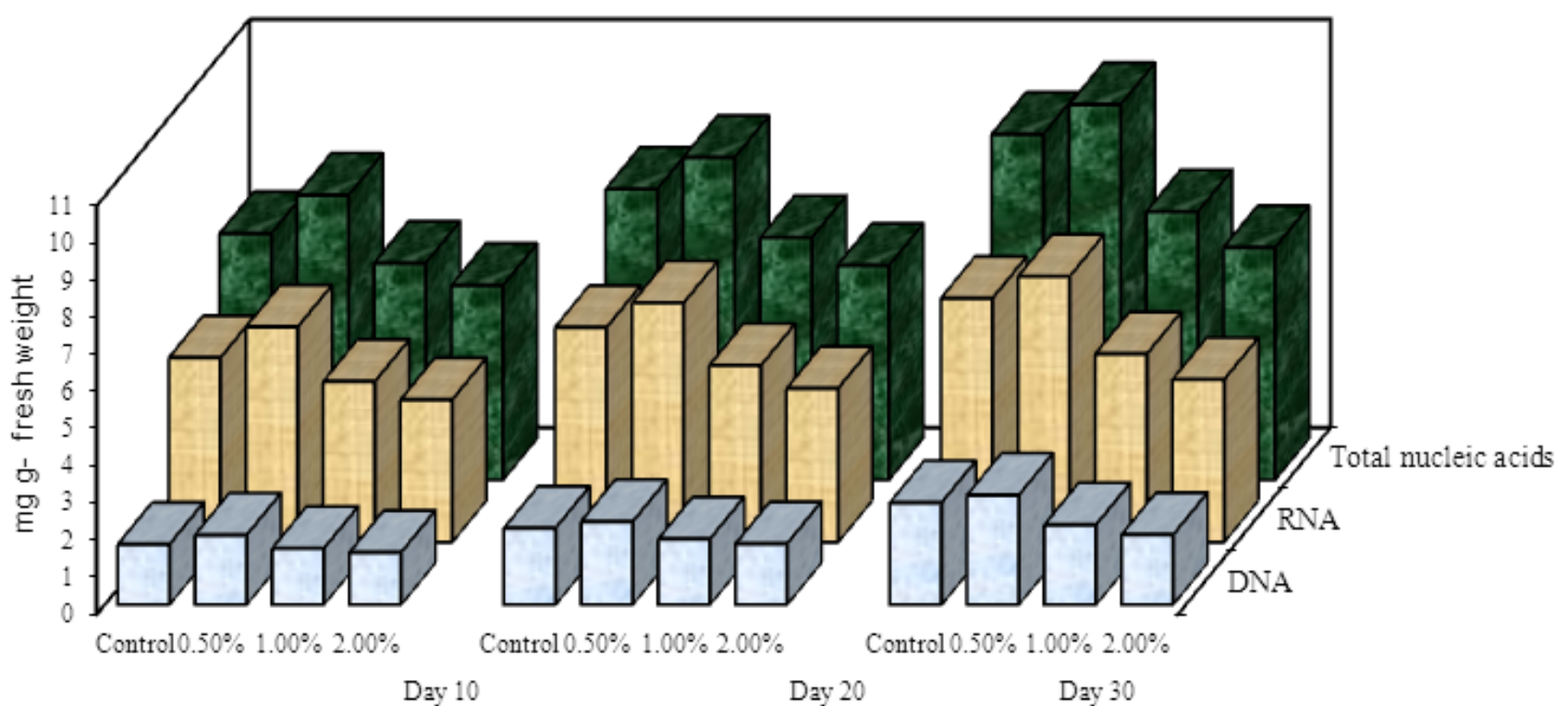

Eucalyptus rostrata leaf residue rate (w/w)

Time $=\mathrm{P}, 0.001$, Treatment $=\mathrm{P}<0.001$ and Time-treatment interaction $=\mathrm{P}>0.001$ (DNA), $\mathrm{P}<0.05$ (RNA) \& $\mathrm{P}<0.01$ (Total nucleic acids).

Figure 7. Allelopathic effect of Eucalyptus rostrata leaf residue on the nucleic acid contents of Zea mays plant at different growth periods.

The application of Eucalyptus leaf residue at $0.5 \%(\mathrm{w} / \mathrm{w})$ increased the contents of both DNA and RNA in corn shoot as compared with their respective controls throughout the experimental period (Fig. 7). The high accumulation of nucleic acids was consistent with the accumulation of nitrogen and phosphorus contents. This could be explained that is level of Eucalyptus treatment stimulate nitrogen and phosphorus uptake, as well as increase the incorporation of phosphorus into nucleotides and/or stimulate the enzyme system involved in the biosynthesis of new nucleic acids. Also, Baziramakenga et al. (1997) reported that low concentrations of benzoic, cinnamic, vanillic and ferulic acids stimulated the biosynthesis of nucleic acids by increasing the incorporation of ${ }^{32} \mathrm{P}$ into DNA in soybean plant. On the other side, the higher rates (1 and 2\%) of Eucalyptus leaf residue reduced the contents of nucleic acids. Early, Svensson (1972) demonstrated that coumarin interfere with RNA and DNA metabolism. Similarly, Van Sumere et al. (1975) suggested that the reduction of nucleic acid contents in soybean treated with phenolic acids was attributed to the enhancement of the hydrolysis of DNA and RNA. Recently, Seigler (1996) demonstrated that allelopathic compounds interact with nucleic acid metabolism causing modification of DNA and RNA.

The allelopathic potential of Eucalyptus leaf was correlated with the amount of phenolic compounds released from air dried mature leaf residue. The stimulation effect of these compounds at lowest level on corn plant result from the combined action of a number of allelochemicals on different cellular sites of action. Thus, the overall effect of one plant species on another may be the product of multiple and complex interaction of these compounds that may act simultaneously. In this regard, Reigosa et al. (2000) and Einhellig (2001) reviewed some information about the mechanism of action of allelochemicals on various physiological and biochemical process in the plants.

In conclusion, allelopathic interactions of Eucalyptus rostrata allelochemicals include both stimulatory and inhibitory effects on corn plant. The current study reveals that the high accumulation of Eucalyptus rostrata leaves on the soil surface may be responsible for retardation of growth of corn and consequently reduces the plant yield, while the low accumulation could improve the growth and productivity of corn.

\section{REFERENCES}

[1] Abu El-Soud, W. M. (2001): Allelopathic Potential of Acacia nilotica Tree Leaves on the Metabolic Changes of Pea (Pisum sativum). M. Sc. Thesis, Faculty of Science, Cairo University, Egypt.

[2] Al-Wakeel, S. A. M. and Soliman, M. H. (1994): Allelopathic effects of lupin extracts on some physiological aspects in soybean plants. Bull. Egpt. Soc. Physiol. Sci., 14: 124-138.

[3] Anaya, A. L. (1999): Allelopathy as a tool in the management of biotic resources in agroecosystems. Crit. Rev. Plant Sci., 18: 6, 697-739.

[4] AOAC (1990): In: “Official Methods of Analysis". The Association of Official Analytical Chemists. Tanni, $15^{\text {th }}$ Edn. PP. 746. Washington, D. C.

[5] Balasubramanian, A. and Ravichandran, V. K. (1996): Allelopathic significance of six agroforestry trees on Casuarina equisetifolig growth and nodulation. Madras Agri. J., 83: 84-87.

[6] Baziramakenga, R.; Simard, R. R. and Leroux, G. D. (1994): Effects of benzoic and cinnamic acids on growth, mineral 
composition and chlorophyll content of soybean. J. Chem. Ecol., 20: 2821-2833.

[7] Baziramakenga, R.; Simard, R. R.; Leroux, G. D. and Nadeau, P. (1997): Allelopathic effects of phenolic acids on nucleic acid and protein levels in soybean seedlings. Can. J. Bot., 75: $445-450$.

[8] Boulos, L. and El-Hadidi, M. N. (1988): Family: Myrtaceae. In: "The Street Trees of Egypt". (L. Boulous and M. N. El-Hadidi, eds.) pp. 76-79. The Amer. Univ. Cairo Press, Egypt.

[9] Cameron, H. j. and Julian, G. R. (1980): Inhibition of protein synthesis in lettuce (Lactuca sativa L.) by allelopathic compounds J. Chem. Ecol., 6: 989-995.

[10] Campbell, R. C. (1989): In: "Statistics for Biologists". $3^{\text {rd }}$ Edn., Cambridge Univ. Press, Cambridge.

[11] Chaney, A. L. and Marbach, E. P. (1962): Modified reagents for determination of urea and ammonia. Clin. Chem., 8: 130-132.

[12] Clark, J. M. and Switzer, R. L. (1977): In: “Experimental Biochemistry". $2^{\text {nd }}$ Edn., Freedman and Company, San Francisco.

[13] Cosio, E. G. and McClure, J. W. (1984): Kaempferol glycosides and enzymes of flavonol biosynthesis in leaves of a soybean strain with low photosynthetic rates. Plant Physiol., 74: 877-881.

[14] Einhellig, F. A. (2001): The Physiology of Allelochemical Action: Clues and Views. Proc. $1^{\text {st }}$ European Allelopathy Sym. on "Physiological Aspects of Allelopathy". (M. J. Reigosa and N. P. Bonjoch, eds.) pp. 3-26. GAMESAL, S. A., Vigo, Spain.

[15] Espinosa-Garcia, F. J. (1996): Revision sobre la alelopatia de Eucalyptus L'Herit. Bol. Soc. Bot. Mexico, 58: 55-74.

[16] Fadeel, A. A. (1962): Location and properties of chloroplast and pigment determination in roots. Physiol. Plant., 15: 130-147.

[17] Gaines, T. P. (1973): Automated determination of reducing sugars, total sugars and starch in plant tissue from one weighted sample. J. Assoc. Off. Anal. Chem., 56: 1419-1424.

[18] Gallet, C.; Nilsson, M. -C. and Zackrisson, O. (1999): Phenolic metabolites of ecological significance in Eucalyptus hermaphroditum leaves and associated humus. Plant Soil, 210: 1-9.

[19] Hejl, A. M.; Einhellig, F. A. and Rasmussen, J. A. (1993): Effects of juglone on growth, photosynthesis, and respiration. J. Chem. Ecol., 19: 559-568.

[20] Hrazdina, G. and Wagner, G. J. (1985): Compartmentation of plant phenolic compounds: Site of synthesis and accumulation. In: "The Biochemistry of Plant Phenolics". (C. F. Van Sumere and P. J. Lea, eds.) pp. 119-134. Clarendon Press, Oxford.

[21] Huang, Z. L.; Lin, S. X. and Tan, S. M. (1994): Review on the rooting inhibiting substances in Eucalyptus. South China Agricultural Univ., Forest Res., 7: 319-324.

[22] Igboanugo, A. B. I. (1988): Effects of some Eucalyptus on yields of Vigna unguiculata L. walp., Zea mays L. and Sorghum bicolor L. Agri. Ecosys. and Envi., 24: 453-458.
[23] Jayakumar, M.; Eyini, M. and Pannirselvam, S. (1990): Allelopathic effect of Eucalyptus globulus Labil on groundnut and corn. Comp. Physiol. Ecol., 15: 109-113.

[24] Jindal, K. K. and Singh, R. N. (1975): Phenolic content in male and female Carica papaya: A possible physiological marker sex identification of vegetative seedlings. Physiol. Plant., 33: 104-107.

[25] Jose, S. and Gillispie, A. R. (1998): Allelopathy in black walnut (Juglans nigra L.) alley cropping. II- Effects of juglone on hydroponically grown corn (Zea mays L.) and soybean [Glycine max (L.) Merr.] growth and physiology. Plant Soil, 203: 199-205.

[26] Kleiner, K. W.; Raffa, K. F. and Dickson, R. E. (1999): Partitioning of ${ }^{14} \mathrm{C}$ - labeled photosynthate to allelochemicals and primary metabolites in source and sink leaves of aspen: Evidence for secondary metabolite turnover. Oecologi, 119: 408-418.

[27] Kohli, R. K.; Daljit-Singh and Singh, D. (1991): Allelopathic impact of volatile components from Eucalyptus on crop plants. Biologia. Plant., 33: 6, 475-483.

[28] Konar, J. and Kushari, D. P. (1995): Effects of Eucalyptus globulus leachates on the growth and diosgenin content of Costus speciosus. Allelopathy J., 2: 215-218.

[29] Kumar, D. (1986): Place of Eucalyptus in indian agroforestry systems. In: "Eucalyptus in India: Past, Present and Future." (J. K. Sharma; C. T. S. Nair; S. Kedharnath and S. Kondas, eds.) pp. 257-260. Kerala Forest Research Institute, Kerala, India.

[30] Lisanework, N. and Michelsen, A. (1993): Allelopathy in agroforestry systems: The effects of leaf extracts of Eucalyptus lusitanica and three Eucalyptus spp. on four Ethiopian crops. Agrofor. Systems, 21: 63-68.

[31] May, F. E. and Ash, J. E. (1990): An assessment of the allelopathic potential of Eucalyptus. Aust. J. Bot., 38: 245-252.

[32] Mersie, W. and Singh, M. (1988): Effects of phenolic acids and ragweed parthenium (Parthenium hysterophorus) extracts on tomato (Lycopersicon esculentum) growth and nutrient and chlorophyll content. Weed Sci., 36: 278-281.

[33] Mersie, W. and Singh, M. (1993): Phenolic acids affect photosynthesis and protein synthesis by isolated leaf cells of velvetleaf. J. Chem. Ecol., 19: 1293-1301.

[34] Mohamed, Y. A. H. and El-Sayed, M. A. (1982): The role of cobalt in nucleic acid content of Azotobacter chroocaccum. Iraqi J. Sci., 23: 421-424.

[35] Nishimura, H. and Mizutani, J. (1995): Identification and allelochemicals in Eucalyptus citriodora and Polygonum sachalinense. In: "Allelopathy: Organisms, Processes and Applications". (Inderjit; K. M. M. Dakshini and F. A. Einhellig, eds.) pp. 74-85. Amer. Chem. Soci., Washington, D. C.

[36] Patterson, D. T. (1981): Effects of allelopathic chemicals on growth and physiological responses of soybean (Glycine max). Weed Sci., 29: 53-59.

[37] Phlomina, N. S. and Srivasuki, K. P. (1996): Allelopathic studies on agroforestry species: Effect of leaf leachates on seed germination of crop plants. Indian J. Forestry, 19: 45-53. 
[38] Prasad, M. N. V. and Subhashini, P. (1994): Mimosine-inhibited seed germination, seedling growth and enzymes of Oryza sativa L. J. Chem. Ecol., 20: 1689-1696.

[39] Prasad, M. N. V. and Rama Devi, S. (2001): Physiological basis for allelochemical action of ferulic acid. Proc. $1^{\text {st }}$ European Allelopathy Sym. on "Physiological Aspects of Allelopathy". (M. J. Reigosa and N. P. Bonjoch, eds.) pp. 27-45. GAMESAL, S. A., Vigo, Spain.

[40] Reigosa, M. J.; Sanchez-Moreiras, A. and González, L. (1999): Ecophysiological approach in allelopathy. Critical Rev. Plant Sci., 18: 577-608.

[41] Reigosa, M. J.; González, L.; Souto, X. C. and Pastoriza, J. E. (2000): Allelopathy in forest ecosystems. In: "Allelopathy in Ecological Agriculture and Forestry". (S. S, Narwal et al., eds.) pp. 183-193. Kluwer Academic Publishers, Netherlands.

[42] Rice, E. L. (1984): In: “ Allelopathy”. $2^{\text {nd }}$ Edn. pp. 422. Academic Press, Orlando, Florida.

[43] Russell, J. A. (1944): Note on the colorimetric determination of amino nitrogen. J. Biol. Chem., 156: 467-468.

[44] Sajjan, A. S; Hiremath, S. M. and Badanur, V. P. (1997): Allelopathic effect of Eucalyptus on germination and seedling. Ann. Plant Physiol., 11: 54-57.

[45] Salama, A. M.; Ismail, I. M. K.; Ali, M. I. A. and Ouf, S. A. (1990): Identification of the phenolic compounds from Eucalyptus rostrata leaves. Egypt J. Physiol. Sci., 14: 75-80.

[46] Sato, T. ; Kiuchi, F. and Sankawa, U. (1982): Inhibition of phenylalanine ammonia - lyase by cinnamic acid derivatives and related compounds. Phytochemistry, 21: 845-850.

[47] Schon, M. K. and Einhellig, F. A. (1982): Allelopathic effects of cultivated sunflower on grain sorghum. Bot. Gaz., 143: 505-510.

[48] Schneider, W. C. (1945): Phosphorus compounds in animal tissue. I. Extraction and estimation of desoxypentose nucleic acid and pentose nucleic acid. J. Biol. Chem., 161: 293-303.
[49] Seigler, D. S. (1996): Chemistry and mechanisms of allelopathic interactions. Agron. J., 88: 876-885.

[50] Sestak, Z.; Catsky, J. and Jarvis, P. G. (1971): Determination of chlorophylls $a$ and $b$. In: "Plant Photosynthetic Production". Manual Methods. (Z. Sestak; J. Catsky and P. G. Jarvis, eds.) pp. 672-679. Dr. W. Junk Publ. The Hague.

[51] Singh, D. and Kohli, R. K. (1992): Impact of Eucalyptus tereticornis Sm. shelterbelts on crops. Agrofor. Syst., 20: 253-266.

[52] Sivagurunathan, M.; Devi, G. S. and Ramasamy, K. (1997): Allelopathic compounds in Eucalyptus spp. Allelopathy J., 4: 313-320.

[53] Srivastava, S.; Tripathi, A. K. and Jain, A. (1996): Phytochemical investigation of some forest tree species for their allelopathic potential. Indian J. Ecol., 23: 21-28.

[54] Streeter, J. G. and Jeffers, D. L. (1979): Distribution of total non-structural carbohydrates in soybean plants having increased reproductive load. Crop Sci., 19: 729-734.

[55] Suresh, K. K. and Vinaya Rai, R. S. (1987): Studies on the allelopathic effects of some agroforestry tree crops. Internat. Tree Crops J., 4: 109-115.

[56] Svensson, S. B. (1972): The effects of coumarin on growth, production of dry matter, protein and nucleic acids in roots of maize and wheat and the interaction of coumarin with metabolic inhibitors. Physiol. Plant., 27: 13-24.

[57] Tripathi, S.; Tripathi, A.; Kori, D. C. and Tiwari, S. (1998): Effect of tree leaves aqueous extracts on germination and seedling growth of soybean. Allelopathy J., 5: 75-82.

[58] Van Sumere, C. F.; Albrecht, J.; Dedonder, A.; De Pooter, H. and Pé, I. (1975): Plant proteins and phenolics. In: "The Chemistry and Biochemistry of Plant Proteins". (J. B. Harborne and C. F. Van Sumere, eds.) pp. 212-264. Academia Press, London. 